Отримано: 2 грудня 2019 року

Прорецензовано: 9 грудня 2019 року

Прийнято до друку: 11 грудня 2019 року

e-mail: valerymykhaylenko@i.ua

DOI: $10.25264 / 2519-2558-2019-8(76)-64-67$
Valery Mykhaylenko. Correlation of linguistic and cultural in the gender shift of the noun. Наукові записки Наиіонального університету "Острозька академія»: серія "Філологія». Острог: Вид-во НаУОА, 2019. Вип. 8(76), грудень. С. 64-67.

Valery Mykhaylenko,

Doctor of Philology, professor

King Danylo University, Ivano-Frankivsk,

\title{
CORRELATION OF LINGUISTIC AND CULTURAL IN THE GENDER SHIFT OF THE NOUN
}

The objective of the present article is twofold, first, I intend to illustrate the tendences of expanding the feminine forms of agent-meaning nouns (Mykhaylenko, 2015) in the Ukrainian language due to the split of the masculine or common gender form and, second, I plan to hightlight the models of translation of Ukrainian feminine agent nouns into English. My hypothesis lies in the following: in translating the Ukrainian agentive nouns the change of feminine into masculine occurs and in case of translating English agentive nouns of the masculine (common) gender into Ukrainian the process of 'domestication occurs that will be proved in the next publication. Corbett(1991)acknowledges that grammatical gender is a multilevel phenomenon - morphological, semantic (overt and covert), and syntactical. It becomes obvious, particularly, in gender assignment to human (agent) nouns, where most nouns referring to women are feminine, and those referring to men are masculine. The definition of agreement itself becomes important but, in the vast literature on gender, there seems to be no unanimous opinion on tis phenomenon and its role in defining the nоun gender. Корпусний аналіз висвітлив деякі випадки використання однієї тієі ж номінації в жіночому та чоловічому роді в реченні, наприклад, міністр та міністерка, щзо свідчить про те, щзо ие явище ще знаходиться в проиесі стабілізаиіі.

Key words: masculine, feminine, agent noun, transform, agreement, translation.

\author{
Михайленко Валерій Васильвич, \\ доктор філологї, професор \\ Університет Короля Данила, Івано-Франківськ
}

\section{КОРЕЛЯЦІЯ МОВНОГО ТА КУЛЬТУРНОГО ПРИ ЗМІНІ РОДУ ІМЕННИКА}

Мета даної статті двояка, по-перше, проілюструвати тенденції до розширення жіночої форми агентивних іменників (Михайленко, 2015) в украӥнській мові завдяки поділу форми чоловічого (загального) роду, по-друге, вирізнити моделі перекладу украӥнських іменників жіночого роду на англійську мову. Моя гіпотеза полягає в тому, щуо при перекладі агентивних іменників на англійську мову відбувається нейтралізація, при зворотньому перекладі агентивних іменників жіночого роду з англійськоӥ на украӥнську відбуватися так зване 'одомашнення', що буде продемонстровано у подальшій публікації. Корпус фактів отримано із джерел масової інформації: украӥнських та англійських газет, радіо та телебачення.

Ключові слова: чоловічий, жіночий, агентивний іменник, узгодження, переклад.

PRELIMINARIES. Gender" as an interdisciplinary concept and term that refers to the way different sexes are culturally constructed depending on the time, place and group in which women and men live [see 10, p.192], entered the field of Translation Studies as an analytical category in the late 1980s [6]. Castro says that the globalisation of culture and the internationalisation of discourses bring the societies to interacting through translation [3, p.6; see also 15, p.135]. Vermeer writes that translation involves linguistic as well as cultural phenomena and processes and therefore is a cultural as well as linguistic procedure [18, p.40]. It is important to note that this transfer implies an ideological transfer as well, if ideology is understood in its broad sense [11, p.25]. Butler stresses that there can be no theory of gender without translation and that Anglophone monolingualism too often assumes that English forms a sufficient basis for theoretical claims about gender [see 2].

The objective of this article is twofold, first, I intend to illustrate the tendences of expanding the feminine forms of agent-meaning nouns [see10, p.327-329] in the Ukrainian language due to the split of the masculine or common gender form and, second, I plan to hightlight the models of translation of Ukrainian feminine agent nouns into English.

My hypothesis lies in the following: in translating the Ukrainian agentive nouns of feminine gender into English the gender neutralization takes place, i.e, the change of feminineinto masculine and in case of translating English agentive nouns of the masculine (common) gender into Ukrainian the process of 'domestication occues,' i.e the change of masculine (common), that will beproved in the next publication. The data is retrieved from mass media sources: Ukrainian and English newspapers, Radio and TV discourse.

DISCUSSION. In recent years, a considerable volume of academic literature and researches in the field of translation are being focused on the concept of gender in translation (Chamberlain, 1992, Simon 1996, von Flotow 2001, Livia, 2003, Talbot, 2003, Golovar, 2009, Castro, 2013, Butler, 2019). Ukrainian nouns are distinguished by gender: masculine, feminine, and neuter; therefore they can be replaced with pronouns $h e$, she, or $i$, depending on their gender. Bilaniuk writes that her analysis focuses on language ideologies and attitudes, based on survey and matched-guise language attitude test data [1, p.49-50]. Naturally, gender is often thought of in terms of bipolar categories, sometimes even as mutually exclusive opposites - as in «the opposite sex»[17, p.468; Hellinger and Bussmann, 2001]. Corbett acknowledges that grammatical gender is a multilevel phenomenon - morphological, semantic (overt and covert), and syntactical. It becomes obvious, particularly, in gender assignment to human (agent) nouns, where most nouns referring to women are feminine, and those referring to men are masculine [5, p. 557]. R.Quirk et al. classify the nouns on the basis of their pronoun coreference into nine gender classes. In the personal gender class the authors specify the personadual gender nouns, which has who-he orshe pronoun corefernce, for instance, artist, librarian, etc. [14, p.315]. The determining criterion of gender is agreement, for example, two genders implies that there are two classes of nouns, which can be distinguished syntactically, according to the agreements they are marked with. Thus, the definition of agreement itself becomes important but, in 
the vast literature on gender, there seems to be no unanimous acceptance of what agreement means [cf.5] and a bone of contention is often whether or not agreement includes the control of anaphoric pronouns by their antecedent, e.g. the husband... he, or in Quirk's terms "pronoun coreference

Gender in translation is an unprecedented study of panoramic feminist issues surrounding translation studies. There is a decisive impact of feminism on translation theory and therefore feminist theorists have drawn attention to the ways in which translators contribute to cultural debates as a means of literary activism [15]. The differences between source and target language may be accompanied by differences in culture and period, thus translators often work with both morphological gender and cultural gender [9, p.142 ]. According to Livia, "when translating from a language in which there are many linguistic gender markers into a language which has fewer, either gender information is lost, or it is overstated, overtly asserted where in the original it is more subtly presupposed [9, p. 157].

CORPUS ANALYSIS. It is generally accepted that languages can be classified according to whether they show grammatical gender or not.

Each noun is of a particular gender regardless of whether it's a living creature, a thing, or an abstract idea. Endings of nouns, which change as required by their positions in a sentence, can serve as an indicator of gender. All Ukrainian nouns have gender: masculine, feminine (becausethey refer to "biological entities"and neuter. A number of nouns ending in a hard consonentand referring to people are ultimately borrowngsfrom Europian languages. They may be grammatically masculine, but they all express both sexes and can be called "common gender" nouns [13, p.47]. The true gender of such nouns can be decoded with the help of their aggreement (corefernce) with the following Past Sg verb form, or the personal pronoun singular he/she. In Engish many nouns that refer to people's roles and jobs can be used for either a masculine or a feminine subject, for example, cousin, teenager, friend, colleague. Common nouns refer to members of a species and don't differentiate the gender (i.e. parent, friend, client, student, etc.). Due to its dependency on societal and chronological conditions, the assignment of social gender frequently turns out to be a rather complicated part of the translation process. The following examples are intended, on the one hand, to demonstrate some ways in which translators have tried to disentangle the problems and, on the other hand, to show that the choices made imply ideological considerations as well. English has a pronominal gender system based on semantic criteria that is reflected only in personal possessive and reflexive third-person pronouns. In the following section we shall correlate to gendersystems, Ukrainian and English through comparing two modelsof translation triggers [see multilingual study: 8, p.21-22:]

(i) Ukr. Sg. Masculne. керівник from Polish kierownik, голова, feminine керівниця $\rightarrow$ Engl.Sg. head, Ukr.Pl. керівники, голови $\rightarrow$ Engl. Pl.heads.

1.1. У Запоріжжі напали з ножем на керівницю громадської організації «Запорізький ромський центр «Лачо Дром»

1.2. Belova heads Lacho Drome, a Roma center in Zaporizhia.

Ukr. керівник/ керівниця / управляти rendered by Engl. head/n

(ii) Ukr. Sg. Masculine голова, feminine голова, керівниця $\rightarrow$ Eng. Sg. Masculine.(common) head; Ukr. Pl. голови/керівники $\rightarrow$ Engl. Pl. heads

2.1. Голові Херсонської обласної ради Владиславу Мангеру оголосили підозру в організації вбивства активістки $і$ чиновнииі Катерини Гандзюк.

2.2. Head of Kherson Oblast council named as suspect in murder of activist Gandziuk.

Ukr. голова (герівник установи, об'єднання, товариства, організації та їх відділів) is rendered by its corresponding noun head (Webster: director, leader). Here we can find the Ukrainian noun голова which gender is either masculine, or feminine are differented by the theiraggreement with the proper names, though the masculine gende was preferred [see,12, p.305-306].

(iii) Ukr. Sg. Masculine активісm (probably from Swedish in the1920s), feminine активістка $\rightarrow$ Engl.Sg. activist, Ukr.Pl. активісти $\rightarrow$ Engl. Pl.activists

3.1. Активістка Українського культурного центру Павленко виїхала з Криму

3.2. Kherson activist Kateryna Handziuk dies after savage acid attack.

3.3.1 Я вважаю себе активістом Майдану, і ие головний вчинок, який я зробив у своєму житті.

3.3.2. Oleg Sentsov, Ukrainian filmmaker and activist, wins EU's Sakharov Prize

(iv) Ukr. Sg. masculine радник from German Berater,feminine радниця -- Engl.(common) adviser; Ukr.Pl. радники, радниці $\rightarrow$ Engl. Pl advisers.

4.1. До нападу активістка була радником мера міста В. Миколаєнка

4.2. Gandziuk ... worked as an adviser to the mayor of Kherson

4.3. Нинішня радниця міністра охорони здоров'я оновила декларацію на посаду заступниці міністра.

(v) Ukr. Sg Masculine (common) уповноважений, feminine уповноважена, омбудсмен, комісар, Engl.(common) commissioner (from Medieval Latin commissionarius), Engl. Sg. Commissioner, ombudsman (from Swedish), Ukr.Pl. уповноважені, омбудсмени, комісари $\rightarrow$ Engl.Pl. Ombudsmen, commissioners

5.1. ВР України з прав людини Людмила Денісова звернулась до російського омбудсмена Тетяни Москалькової.

In this case уповноважений reveals the masculine genderwhich does not aggree with the fiminine gender of the proper name Людмила Денісова.

5.2. Liudmyla Denisova, the Ukrainian parliament's commissioner for human rights, wrote in 2018 after more than 110 Ukrainians were imprisoned in Greece on charges of smuggling migrants.

5.3.1.Український омбудсмен Людмила Денісова звернулася до керівництва Морського центру порятунку та координації

5.3.2. Ukraine's Ombudsman Lyudmyla Denisova and European External Action Service officials discussed the release of Ukrainian political prisoners and prisoners of war from Russian captivity.

In illustration (5.1.) the masculine gender уповноважений does not aggree with the proper noun Людмила Денісова,likewise the gender of омбудсмен does not aggree with the proper name Тетяни Москалькової. There is one more finding in the Ukrainian language - the agent nouns borrinowed from other European languages retain their masculine (common) gender in Ukrainian.

(vi) Ukr. Sg. Masculine (common) директор (from Anglo-French 
directour, French directeur, agent noun from Latin dirigere), feminine директорка or директор $\rightarrow$ Engl.Sg. (common) director, Ukr.Pl. директори $\rightarrow$ Engl. Pl.directors.

6.1 Світовий конгрес українців (СКУ) після тривалого глобального конкурсу призначив Марію Купріянову виконавчим директором.

6.2. Ukrainian World Congress (UWC) has appointed Mariia Kupriianova as its Executive Director, according to the UWC website.

6.3. «Коли я прийшла сюди працювати, сказала колегам: «Я не хочу, щоб дітей тут вчили так, як мене», - зустрічає нас Ірина Хміль, директорка End

The word schoolmaster, or simply master, formerly referred to a male school teacher. NOTE: Ukr директор школи is rendered as a headmaster or a school master (British English) and principal (American English).

The term директор (mascular or common) which can agreewith masculine and feminine proper names. Вut the term директорка is feminine due to the feminine suffix -ка and the Past form of the verbs: прийшла, сказала.

The Ukrainian terms директор, директорка (company, enterprise, institution, etc.)can be rendered in English as manager or C.E.O., for instance:

6.4.1. Це все інвестиційні кредити, тобто позики на купівлю виробничого обладнання, - розповідає директорка компанії Роксолана Вакуленко

6.4.2. Michelle Nitchie became head of Design and Development in the summer of 2009 after her previous work as a Project Manager.

In (6.4.2.) the term manager can be rendered as директорка оr очильниия.

(vii) Ukr. Sg. Masculine (common) міністер (from Old French menistre «servant, administrator, etc," 12c.), Sg.feminine міністер, міністерка $\rightarrow$ Engl. Sg. minister, Ukr. Pl. міністри $\rightarrow$ Engl. Pl. ministers.

7.1. Оксана Маркарова -від серпня вже міністерка фінансів в уряді під керівництвом Олексія Гончарука.

7.1.1. Гість програми «Ваша Свобода»: міністр фінансів України Оксана Маркарова.

7.2.1. Ukrainian finance minister: Gambling revenues may reach 5-9 bln

7.2.2. Minister of Finance Oksana Markarova presented the draft Law of Ukraine "On the State Budget of Ukraine for 2020".

7.3.1. Працівники міністерства охорони здоров'я України заявляють про загрозу зриву медичної реформи та політичний тиск від команди нової міністерки Зоряни Скалецької.

7.3.2. Ukrainian Health Minister says she is convinced that there were «misunderstandings» within her Ministry as the inconsistency in its structure «delays the solution of numerous issues,» although certain progress is being seen.

In English the gender of minister can be decoded from its aggreement with the proper name. In Ukrainian there is an additional gender marker -- the Past sg verb form of thepredicate.And the feminine suffix -ка becomes popular in mass media

(viii) Ukr. Sg. Masculine журналіст ( from French journaliste (see journal (n.) + -ist)., Sg. feminine журналістка, Engl.Sg. journalist; Pl. Ukr журналісти $\rightarrow$ Engl.Pl. journalists

8.1. Переможницею конкурсу на посаду прес-секретаря Президента Володимира Зеленського стала журналістка Юлія Мендель.

8.2. Journalist Yulia Mendel became the winner of the competition for the position of the Press Secretary of President of Ukraine.

The feminine журналістка has become a regular nomination.

(ix). Ukr. Sg. Masculine (common) мер (from Old French maire «head of a city or town government» (13c.), originally «greater, superior» (adj.), from Latin maior, major, comparative of magnus «great, large, big» (of size), «abundant» (of quantity), «great, considerable» (of value), «strong, powerful» (of force); of persons, «elder, aged,» also, figuratively, «great, mighty, grand, important,» from PIE *mag-no-, from root *meg- «great»), Sg.,feminine мер $\rightarrow$ Engl mayor; Ukr. Pl. мери $\rightarrow$ Engl.Pl. mayors.

9.1. Україна має виплатити колишньому меру Слов'янська Донецької області Нелі Штепі 3600 євро компенсації.

9.2.The European Court of Human Rights (ECHR) has ordered Ukraine to pay former Sloviansk Mayor Nelia Shtepa EUR 3,600.

The borrowing mayor is used in the common gender of the Source and Target

Languages and the gender is ctualized due to theaa ggreement.

(x) Uk. Sg. Masculine (common)художник митець,Sg.,feminine хуложниця місткиня $\rightarrow$ Engl.Sg. artist (from Middle French artiste (14c.), from Italian artista, from Medieval Latin artista, from Latin ars0 Ukr.P1. художники, художниці, митці, мисткині $\rightarrow$ Engl.Pl. Ukr. artists.

10.1. Ольга Кондрацька - сучасна художниця, член Американського інституту

Експозиція становитиме своєрідну лабораторію мисткині, в якій поруч із закінченими роботами

10.2.Exhibition of contemporary artist Olga Kondratska opens at Ukrinform

10.3. Найвідоміший український художник Іван Марчук відкрив у київському мистецькому просторі ARTAREA свою виставку Секрети геніальност.i in Kyiv

10.3.1.World-renowned Ukrainian artist Ivan Marchuk has opened his exhibition Secrets of Genius at the ARTAREA art space

The feminine мисткиня (cf masculine митець/мистець) becomes also popular in the contemporary Ukrainian mass media.

The list of Ukrainian agent nouns which add the feminine suffixes ( $є$-к-, -иц-, -ин-, -ес-) can be continued, some of them are used regularly in the Western parts of Ukraine, like плавчиня, майстриня and others due to the mass media become frequent (очільниия, речниия, депутатка, модераторка) in most of the country. We have demonstrated the patterns of translating Ukrainian feminine agent nouns into English which prove the thesis that translation synthesizes linguistics and culture [cf.16, p.79-80]. And the choice of the language unit much depends upon the translator/interpreter who can either show the changes in the language reflecting the changes in the society, or avoid them following the older forms [see 4]. But we do not introduce so-called stereotypes, because the language is in a constant flow as well as the society [see 17, p.472]. We hope that we have met Livia's challenge who says that "if the languages encode gender in very different ways, translators need to devise a system to encompass the differences" [9, p.154]. The translator/interpreter as yin-yang'is a linguist and a cultural guide. 
FINDINGS AND PERSPECTIVES. The investigation of the gender transformation of Ukrainian agent-meaning nouns in Mass Media Discourse reveals that the English translator does not take into consideration the Ukrainian culture and the present day social changes in the country which are mirrored in the language and namely in the gender system. When we translate we should keep in mind that in translation/interpreting linguistics and culture are closely related. No doubt, the reader/listener is the ultimate appraiser of the Target Text. And the text must not be either domesticised or foregnised. In both cases the text misses the cultural component of the Source language. As a perspective of our further reseach we plan to have a field study of penetrating feminitives which may substitute masculine correspondences into other registers of discourse. Primarily, I must embark on the semantic classification of Ukrainian agentive nouns which are differentiated into masculine and feminine genders.

\section{References:}

1. Bilaniuk Laada. Gender, language attitudes, and language status in Ukraine. Language in Society. 2003. Vol.32. No.1. P. 47-78

2. Butler Judith. Gender in Translation: Beyond Monolingualism. PHILOSOPHIA. 2019.Vol. 9. No 1. P. 1-25.

3. Castro Olga. Introduction: Gender, language and translation at the crossroads of discipline. G\&L. 2013 Vol 7. No1. P.5-12.

4. Chamberlain Lori. Gender and the metaphorics of translation. / Ed. L. Venuti Rethinidng Translation: Discourse, Subjectivity, Ideology. London and New York: Routledge,1992. P. 57-74.

5. Corbett G. Gender. Cambridge: Cambridge University Press,1991. 363p.

6. Flotow Luise von. Translation and gender. Translating in the era of feminism. Manchester and Ottava: Saint Jerome Publishing and Ottawa UP, 1997. 114 p.

7. Golovar Ebrahim The Effect of the translator's gender on translation evaluation. Translation Journal. 2009. Vol.13. No2. Online.

8. Hellinger Marlis, Bussmann Hadumod (eds.). Introduction to 'Gender across languages. The linguistic representation of women and men (3 vols.) Amsterdam / Philadelphia, 2001-2003. Vol. 1. P. 1-25.

9. Livia Anna. One man in two is a woman: Linguistic approaches to gender in literary texts. Linguistic approaches to gender / Ed. Janet Holmes and Miriam

10. Mykhaylenko Valery V. Glossary of linguistics and translation studies: English-Ukrainian. Chernivtsi: Tehnodruk, 2015. 555p.

11. Nissen Uwe Kjær. Aspects of translating gender. Linguistics online. 2002.Vol.11. No2. P.25-37.

12. Pavlychko Solomea. Feminism in post-communist Ukrainian society / Ed. R. Marsh. Women in Russia and Ukraine. Cambridge: CUP, 1996. P. 305-314.

13. Press Ian, Pugh Stefan. Ukrainian: A Comprehensive grammar. London, New York: Routledge, 2015. 336 p.

14. Quirk Randolph et al. Comprehensive grammar of the English language. Harlow: Longman, 2000. 1779 p.

15. Simon Sherry. Gender in translation. New York: Routledge, 1996. x,195p.

16. Snell-Hornby Mary. Linguistic transcoding or cultural transfer? A critique of translation theory in Germany / Ed. Susan Bassnett, André Lefevere.Translation, history and culture. London: 1990. P. 79-86.

17. Talbot M. Gender stereotypes: Reproduction and challenge / Ed. J. Holmes and M. Meyerhoff. Handbook of Language and Gender. Oxford: Blackwell Publ., 2003. P.468-86.

18. Vermeer Hans. Is translation a linguistic or a cultural process? Itha do.Desterro. 1992.Vol. 28. P. 37-49. 